\title{
Nutrition, Fats, Saturated
}

National Cancer Institute

\section{Source}

National Cancer Institute. Nutrition, Fats, Saturated. NCI Thesaurus. Code C15825.

Role of saturated fats in cancer causation or prevention and in general health. 